\title{
3 Research Square

\section{Adaptation to Climate Change among Farmers in Drought-Hit Region of Khyber Pakhtunkhwa, Pakistan}

Imtiaz Alam Khan

Institute of Management Peshawar

Muhammad Rafiq

Institute of Management Sciences

Shahab E. Saqib ( $\nabla$ shahabmomand@gmail.com )

Government of Khyber Pakhtunkhwa https://orcid.org/0000-0003-0326-5197

Raza Ullah

University of Agriculture Faisalabad

Muhammad Atiq

Institute of Management Sciences

\section{Research Article}

Keywords: Climate Change impacts, Droughts, Farmers, Adaptation, Risk Management, Khyber

Pakhtunkhwa.

Posted Date: October 28th, 2021

DOI: https://doi.org/10.21203/rs.3.rs-809046/v1

License: (c) (i) This work is licensed under a Creative Commons Attribution 4.0 International License. Read Full License 


\section{Abstract}

The agriculture sector is the most important, however, most vulnerable to climate change in Asia and the Pacific. Droughts are one of the leading sources of disaster risks that can alter yield levels and cause sizeable productivity losses in agricultural products. In response, the farmers are adopting several climate risk management strategies. Therefore, this study aims to find out farmers' preferences for climate change adaptation strategies and their potential determinants. Data were collected from randomly selected 200 farmers in District Nowshehra, Khyber Pakhtunkhwa. A multivariate probit model was used to assess the impacts of various factors on farmers' decisions to adopt a particular adaptation strategy. The findings of the study revealed that rainwater harvesting, change in the planting dates, soil conservation, ponds building, and terraces with spillways were the dominant adaptation strategies found to combat the ill effects of droughts in the study area. Furthermore, the study highlighted the potential role of socioeconomic attributes in the adoption of these adaptation strategies. The findings suggested that the government may extend its support to these farmers in making ponds and providing them the storage of water facilities.

\section{Introduction}

Climate change is one of the most challenging issues of the 21 st century having widespread impacts on the societies and environment (IPCC, 2018). It is posing a serious risk to the global community particularly the developing nations who are continuously facing a vulnerable situation with the increase in intensity and frequency of extreme weather events (Chowdhury et al., 2020). A recent report by the IPCC, (2018) highlighted that by 2050, around 150 million people will be displaced due to climate change-induced phenomena around the world. In the last 50 years, around $79 \%$ of the global disasters involved water, weather, and climate-related hazards are accounted for $56 \%$ of mortalities with a $75 \%$ share in the economic loss (IFRC, 2020). The last decade (2010-2019) saw an increase in the frequency of weather and climate change-related disaster events by around $9 \%$ and $14 \%$ compared to the previous decades i.e. 2000-2010 and 1990-2000, respectively (IFRC, 2020).

Drought is among the many climatic extremes that possess severe impacts observed all over the world with an increasing trend of warming. The demand for precipitation is expected to increase globally owing to the increase in warming conditions (Cook et al., 2014). Unlike other hazards such as floods, earthquakes, and tsunamis, drought can occur anywhere in the world. Furthermore, drought evolves slowly ranging from few months to years of prolonged conditions of water scarcity. The direct consequences of short-term droughts may be loss of crop production, poor pasture growth, and decline in fodder supplies along with long-lasting impacts such as forest fires (Mishra and Singh, 2010). Droughts are considered the most damaging of all hazards owing to their long-lasting socio-economic impacts (Sivakumar et al., 2014). For instance, in the case of United States, drought causes an average of about US\$ 6 to US\$ 8 billion per year (NCDC, 2015). The recent statistics of the average annual economic impact from drought in Europe suggest an increasing trend with an estimated average annual economic loss of $€ 6.2$ billion per year (EEA, 2010). Climate-induced hazards such as floods, droughts, fires are the most damaging for the agriculture sector in Pakistan (Ullah 
and Shah, 2019). The agriculture sector in Pakistan in general and in Khyber Pakhtunkhwa (KP) in particular is confronting with severe floods and weather-related risks (Ahmed et al., 2019).

Droughts impact all sectors of the economy. However, the agriculture sector is the most vulnerable sector to climate change in Asia and the Pacific (ADB, 2009). Climate-induced disasters affect the availability of water to farmers in many regions of the world (Klopper et al., 2006). The risks faced by farmers due to climate change ranges from personal, financial, social, environmental, and others (Iqbal et al., 2016). Farmers' are required to adapt their agricultural activities to maintain their production and reduce their vulnerability to climate change (Hassan and Nhemachena, 2008). The adaptation of farmers to climate change is in response to their perceived vulnerability with the intention to reduce risks associated with farming (Arbuckle et al., 2013). Climate-induced disasters and risks might bring serious negative consequences for agriculture and people associated with agriculture for their livelihood (Gerkensmeier and Ratter, 2018). Therefore, adaptation strategies in the local context are very important to be studied in developing countries like Pakistan.

Keeping in mind the importance of agriculture to the economy and rural livelihoods, the significance of climate change adaptation strategies is crucial (Ali and Erenstein, 2017). Adaptation in the agriculture sector involves practices against changes in the climatic situation. These practices may be in the form of anticipatory adaptation, autonomous adaptation, planned adaptation, even public and private adaptation, and reactionary or reactive adaptation practices (Roka, 2019). The farm-level adaptation strategies are essential for effective policymaking as a tool to manage agriculture-related risks arising from climate change (Hassan and Nhemachena, 2008). Adaptation in the agriculture sector is also important for reducing the impacts of increasing temperature and precipitation across the world (Pradeep and Mendelsohn, 2007). Thus it is equally essential that efforts should be made to increase the resilience and adaptive capacity of a system to overcome the negative impacts of climate change with limiting consequences and damages (Food, 2003). Among the many policy options, adaptation is one of the key options for reducing the harmful consequences of climate change on agriculture (Ozor et al., 2012). An important factor for informing policies aimed at promoting successful adaptation strategies in agriculture is to understand farmers' perceptions regarding climate change, their adaptation strategies, and related factors (Jianjun et al., 2015).

There is extensive literature available on farmers' risk preferences and their role in decisions related to agriculture production (Feder, 1980; Just and Zilberman, 1983; Adger et al., 2009). Studies on risk preferences and adaptation to climate change indicate that the socio-cognitive processes and risk preferences of those involved in decision-making play a crucial role in the promotion of adaptation decisions (Frank et al., 2011; Tam and McDaniels, 2013). Therefore, policymakers need to understand the linkage between farmers' risk preferences and how they respond to the climate change adaptation in order to design effective adaptation strategies (Chavas et al., 2010).

The present study is designed to investigate farmers' preferences about climate change adaptation strategies. Farmers should adopt strategies that are helpful in their struggle against climate change related 
and in-depth insights into the practices of farmer's decision-making under risk. The findings of the study will guide the government agencies to help these farmers in drought situations.

\section{Material And Methods}

\subsection{Study Area and Sampling}

The study in hand was conducted in the Khyber Pakhtunkhwa (KP) province of Pakistan. KP province was purposively selected for this study as farmers in KP face serious challenges of low water use efficiency and lack modern technology, skills, and knowledge to engage in high-value agriculture value chains (World Bank, 2019). Therefore, there is a need for an improved and more climate-resilient community and water management system in KP (World Bank, 2019). District Nowshera of the KP province was purposively selected due to its lowest irrigated land among the five central districts of Khyber Pakhtunkhwa (Government of Khyber Pakhtunkwa, 2014). According to population census 2017, the Nowshera district has a total population of 1,518,540. Among the three Tehsils (sub-districts), of Nowshera, Tehsil Pabbi was purposively selected as the study area for the present research, and data were collected from three purposively selected Union Councils (UCs) namely Spinkhak, Jaroba, and Jalozai Mera as these union councils are mostly exposed to droughts (Adaptation Fund, 2019). Based on the data from population census 2017 and using Yamane, (1967) formula (Eq. 1), a total of 202 sample respondents were selected. Among the three villages, the sample was proportionally distributed. A list of farm households was prepared from the voter lists, villages heads, and village council Nazims. Farmers were randomly selected from the list for the survey. Two respondents were dropped from the analysis due to incomplete data.

$n=\frac{N}{\left(1+N e^{2}\right)}($ Eq. 1)

Where: $\mathrm{N}=$ population size, $\mathrm{n}=$ sample size and $\mathrm{e}=$ precision value set as $5 \%$.

\subsection{Data Collection}

Data were collected through a semi-structured questionnaire. Data were collected on farmers' socioeconomic and demographic factors and their perceptions about climatic risk sources.

\subsection{Data Analysis}

Behavioral response models concerning more than two possible outcomes are either multinomial or multivariate probit models. A total of eight strategies were explored the farmers were practicing in the study area. These were rainwater harvesting, soil conservation, change in planting date, terraces with spillways, ponds, livestock, multiple cropping, and modern irrigation techniques. However, based on frequencies of adoption of the mentioned adaptation strategies among the selected sampled farmers, only five adaptation strategies (rainwater harvesting, soil conservation, change in planting dates, terraces with spillways and ponds) were considered for the present research study. If the adaptation strategies have any possible contemporaneous relationship, then multivariate probit models are used (Ullah and Shivakoti, 2014). A 
multivariate probit model (Eq. 2) was employed to assess the impacts of various independent variables on the decision to adopt the adaptation strategies among the sampled farmers.

$Y_{i j}=x_{i j}^{\prime} \beta_{j}+\epsilon_{i j}$ (Eq. 2)

Where $Y_{i j}(j=1, \ldots, m)$ represent the risk management alternatives (in our case $m=5$ ) faced by the $i^{t h}$ producer $(i=1, \ldots, n), x_{i j}^{\prime}$ is a $1 \times k$ vector of observed variables that affect the decisions to adopt a particular adaptation strategy, $\beta_{j}$ is a $k \times 1$ vector of unknown parameters (to be estimated), and $\epsilon_{i j}$ is the unobserved error term. In this specification, each $Y_{j}$ is a binary variable and thus Eq. 2 is actually a system of $\mathrm{m}$ equations ( $m=5$ in this case) to be estimated:

$Y_{1}^{*}=\alpha_{1}+X i \beta_{i 1}+\epsilon_{1}$ Eq. 3

$Y_{2}^{*}=\alpha_{2}+X i \beta_{i 2}+\epsilon_{2}$ Eq. 4

$Y_{3}^{*}=\alpha_{3}+X i \beta_{i 3}+\epsilon_{3}$ Eq. 5

$Y_{4}^{*}=\alpha_{4}+X i \beta_{i 4}+\epsilon_{4}$ Eq. 6

$Y_{5}^{*}=\alpha_{5}+X i \beta_{i 5}+\epsilon_{5}$ Eq. 7

Where, $Y_{1}^{*}, Y_{2}^{*}, Y_{3}^{*} Y_{4}^{*}$ and $Y_{5}^{*}$ are five latent variables underlying each of the adaptation strategy's adoption decisions such that $\mathrm{y}_{\mathrm{j}}=1$ if $y_{j}^{*}>0$; and 0 otherwise.

\subsection{Study variables}

\subsubsection{Dependent Variables}

The focus of this research is on five dominant strategies found in the study area i.e. on-farm rainwater harvesting, soil conservation tillage, change planting dates, terraces with spillways (TSP), and ponds. These variables were binary in nature: $1=$ adoption, $0=$ no adoption.

\subsubsection{Independent variables}

Research studies have reported that several socio-economic factors influence the adaptation strategies in agriculture in a different context. The socio-economic attributes considered for the present study include age in years (Dadzie and Acquah, 2012; Ullah et al., 2015a) farmers' education (Deressa et al., 2010; Debalke, 2013; Rehima et al., 2013) measured as 1 = literate and 0, otherwise, farming experience (Ashfaq et al., 2008; Mesfin et al., 2011) measured in number of years, number of dependent family members, off farm-income (Velandia et al., 2009; Ullah, 2014; Jianjun et al., 2015; Ullah and Shah, 2019) measured as a categorical variable such that $1=$ monthly income $<$ PKR. 5000 (low), $2=5000-10,000$ and 3 is for $>$ 10,000PKR (high). 
Following Farooqi et al., (2005); Ajani et al., (2013); Abid et al., (2015), and Zulfiqar et al., (2016), the studies also used landholding size, ownership status of the land, farmers' perception of variation in rainfall, and knowledge about climate change. Land ownership status (Velandia et al., 2009) was measured as a binary variable such that $1=$ land owner and $0=$ otherwise. Landholding size (Velandia et al., 2009; Ullah et al., 2015b) was measured in three groups: $1=<5$ acres, $2=5-7.5$ acres, and $3=>7.5$ acres (Saqib et al., 2016a; Saqib et al., 2016b). Perceived rainfall was measured on a five-point Likert scale from 1 (very low) to 5 (very high). Knowledge about climate change was also used as a binary variable; $1=$ Yes and $0=$ No.

\subsection{Ethical Consideration}

The study has been approved by the ethical research committee of Institute of Management Sciences Peshawar. Moreover, written consents were obtained from the study particpants for taking part in interviews.

\section{Results And Discussion}

\subsection{Descriptive Statistics of the study variables}

Summary statistics of the variables considered for the study are presented in Table 1 . The findings revealed that the most prevalent adaptation strategy to cope with the adverse impacts of droughts was rainwater harvesting, with a mean value of 0.86 is ranked as the most dominant strategy to combat the ill impacts of drought in the study area (Table 1). The second most dominant strategy was reported as changing planting dates with a mean value of 0.67 (Rank II). Soil conservation, ponds, and TSP were also practiced by the farmers. It implies that the farmers make preferences when they are adopting different strategies to combat the climate change induced droughts. Most of the farmers in the study area were of a higher age as shown by the mean value of 49.80 years. Less than half were literate (who can read and write) and experienced. The average distance from home to the farm was 705.5 meters. Dependent family members were 3.8 per household. Income from the farm and non-farm activities were falling in the range of PKR.5000-10,000: Rented land was less $(18 \%)$ and mostly farmers (mean $=0.82)$ owned the land. The respondents knew about climate change. 
Table 1

Descriptive Statistics

\begin{tabular}{|lccccc|}
\hline Variables & Min & Max & Mean & SD & Rank \\
\hline Dependent Variables & & & & & \\
\hline RWH & 0 & 1 & 0.86 & 0.37 & I \\
\hline CPD & 0 & 1 & 0.67 & 0.47 & II \\
\hline SC & 0 & 1 & 0.64 & 0.49 & III \\
\hline Ponds & 0 & 1 & 0.63 & 0.48 & IV \\
\hline TSP & 0 & 1 & 0.55 & 0.50 & V \\
\hline Independent Variables & & & & & \\
\hline Age & 25 & 88 & 49.80 & 15.88 & - \\
\hline Literacy & 0 & 1 & 0.43 & 0.50 & - \\
\hline Experience & 5 & 60 & 25.69 & 14.42 & - \\
\hline Dependent family members & 3 & 7 & 3.80 & 1.29 & - \\
\hline Off-Farm Income & 1 & 3 & 2.25 & 0.71 & - \\
\hline Land Ownership & 0 & 1 & 0.82 & 0.39 & - \\
\hline Landholding Size & 1 & 3 & 1.99 & 0.81 & - \\
\hline Erratic Rains & 1 & 5 & 3.9 & 1.42 & - \\
\hline Knowledge about the CC & 0 & 1 & 0.76 & 0.43 & - \\
\hline Source: Survey Data (2015-16) & & & & \\
\hline
\end{tabular}

\subsection{Correlation among Adaptation Strategies}

Correlation coefficients from the multivariate probit model are presented in Table 2. These are the pairwise correlation among the error terms in the equations for the five adaptation strategies. All the correlation coefficients are positive and significant indicating that adoption of one adaptation strategy encourages the adoption of other adaptation strategies. These significant correlation coefficients along with the significant Wald chi $^{2}$ test and the Likelihood Ratio test justify the use of a multivariate probit model. 
Table 2

Correlation coefficients from the multivariate probit model

\begin{tabular}{ll}
\hline Adaptation Strategies & Correlation Coeff \\
\hline rho21 = Soil Conservation and Rainwater Harvesting & $0.595^{\star \star \star}(0.148)$ \\
\hline rho31 = Crop Planting Dates and Rainwater Harvesting & $0.014^{\star \star}(0.121)$ \\
\hline rho41 = Ponds and Rainwater Harvesting & $0.107^{\star}(0.116)$ \\
\hline rho5I = Terraces with Spillways and Rainwater Harvesting & $0.113^{\star}(0.115)$ \\
\hline rho32 = Crop Planting and Soil Conservation & $0.330^{\star \star}(0.131)$ \\
\hline rho42 = Ponds and Soil Conservation & $0.447^{\star \star \star}(0.127)$ \\
\hline rho52 = Terraces with Spillways and Soil Conservation & $0.166^{\star \star}(0.220)$ \\
\hline rho43 = Ponds and Crop Planting Dates & $0.543^{\star \star \star}(0.143)$ \\
\hline rho53 = Terraces with Spillways and Crop Planting Dates & $0.299^{\star \star}(0.130)$ \\
\hline rho54 = Terraces with Spillways and Ponds & $0.219^{\star}(0.114)$ \\
\hline Log-likelihood & -525.65 \\
\hline Wald test chi 2 & 124.93 \\
\hline Likelihood ratio test $\rho_{\mathrm{kj}}$ & $65.60^{\star \star \star}$ \\
\hline Number of observations & 200
\end{tabular}

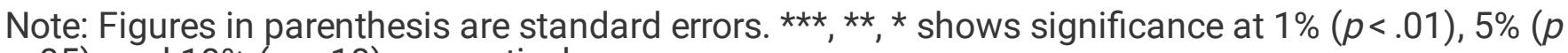
$<.05)$, and $10 \%(p<.10)$, respectively.

\subsection{Results of Multivariate Probit Model \\ 3.3.1 Factors influencing rainwater harvesting}

Results in Table 3 show that education was positively associated with rainwater harvesting coefficient value of 0.4619 and p-value $<0.10$. It implies that as the education increased, the likelihood of rainwater harvesting adaptation was increased. Education enhances the households' head human capital, their "know and how" about the climate change adaptation techniques. Rehima et al., (2013), revealed that education enhances the farmer's ability to apply new production techniques, and do better management at the farm level. The findings of the study are consistent with Deressa et al., (2010). They revealed that education increases the farmers' coping ability with extreme climate conditions in Ethiopia.

Likewise, off-farm income was positively $(0.4461)$ associated with the adoption of rainwater harvesting. It Loading [MathJax]/jax/output/CommonHTML/fonts/TeX/fontdata.js 
According to Ashraf et al., (2014) and Salmoral et al., (2020), off-farm income as risk-mitigating activity that the farmers used to combat the droughts' risks. However, the off-farm income simultaneously induces the farmers to go for rainwater harvesting. Land ownership plays an important role in the adoption of rainwater harvesting. According to Kukkonen and Pott, (2019), "land tenure is a key dimension in any discussion of land-climate interactions." They revealed that in drought situations the farmers are involved in off-farm activities. Similarly, the variable 'erratic rain' was also found positive and significant with a coefficient value of 0.4627 and $p$-value $<0.10$. The adoption of rainwater harvesting was common among those who perceived erratic rains as a source of high risk. The risk perception about the rains that are unstable. The findings of the study are similar to Ullah et al., (2019), who revealed that high-risk perceptions about the heavy rains led to farmers' adaptation to climate-induced floods. However, our case is in droughts. It implies that heavy rains and no rains both are playing important roles in different scenarios of farmers' adaptations. 
Table 3

Multivariate probit model results

\begin{tabular}{|c|c|c|c|c|c|}
\hline $\begin{array}{l}\text { Independent } \\
\text { Variables }\end{array}$ & $\begin{array}{l}\text { Rainwater } \\
\text { Harvesting }\end{array}$ & $\begin{array}{l}\text { Soil } \\
\text { Conservation }\end{array}$ & $\begin{array}{l}\text { Change } \\
\text { Planting Dates }\end{array}$ & Ponds & $\begin{array}{l}\text { Terrace with } \\
\text { Spillways }\end{array}$ \\
\hline \multirow[t]{2}{*}{ Age } & 0.0061 & 0.006 & $0.032^{*}$ & $0.021^{* *}$ & $0.028^{* *}$ \\
\hline & $(0.0150)$ & $(0.015)$ & $(0.018)$ & $(0.010)$ & $(0.014)$ \\
\hline \multirow[t]{2}{*}{ Education } & $0.4619^{*}$ & $0.462^{*}$ & 0.347 & 0.376 & 0.368 \\
\hline & $(0.2546)$ & $(0.255)$ & $(0.243)$ & $(0.237)$ & $(0.228)$ \\
\hline \multirow[t]{2}{*}{ Experience } & -0.0025 & -0.003 & $0.036^{\star *}$ & -0.014 & $-0.025^{\star}$ \\
\hline & $(0.0158)$ & $(0.016)$ & $(0.018)$ & $(0.015)$ & $(0.0143)$ \\
\hline \multirow{2}{*}{$\begin{array}{l}\text { Dependent Family } \\
\text { Members }\end{array}$} & -0.0544 & -0.054 & $0.210^{\star \star}$ & $-0.278^{\star \star \star}$ & -0.068 \\
\hline & $(0.0927)$ & $(0.093)$ & $(0.095)$ & $(0.090)$ & $(0.079)$ \\
\hline \multirow[t]{2}{*}{ Non-Farm Income } & $0.4461^{*}$ & $0.446^{*}$ & $0.511^{* *}$ & 0.020 & $0.379^{*}$ \\
\hline & $(0.250)$ & $(0.251)$ & $(0.234)$ & $(0.221)$ & $(0.228)$ \\
\hline \multirow[t]{2}{*}{ Land Ownership } & $0.162^{\star \star \star}$ & $0.146^{\star \star \star}$ & $0.376^{* *}$ & $0.328^{* \star}$ & -0.026 \\
\hline & $(0.025)$ & $(0.035)$ & $(0.182)$ & $(0.166)$ & $(0.159)$ \\
\hline \multirow[t]{2}{*}{ Landholding Size } & 0.2446 & 0.245 & -0.255 & $0.347^{\star \star}$ & $0.241^{*}$ \\
\hline & $(0.2755)$ & $(0.276)$ & $(0.296)$ & $(0.162)$ & $(0.141)$ \\
\hline \multirow[t]{2}{*}{ Erratic Rain } & $0.4627^{\star}$ & $0.463^{*}$ & $0.574^{\star \star}$ & 0.001 & 0.376 \\
\hline & $(0.275)$ & $(0.275)$ & $(0.273)$ & $(0.238)$ & $(0.233)$ \\
\hline \multirow{2}{*}{$\begin{array}{l}\text { Knowledge about } \\
\text { the CC }\end{array}$} & 0.0836 & 0.084 & $-0.854^{\star \star \star}$ & 0.100 & $0.554^{\star *}$ \\
\hline & $(0.270)$ & $(0.270)$ & $(0.295)$ & $(0.245)$ & $(0.240)$ \\
\hline Log-likelihood & -525.65 & & & & \\
\hline Wald test chi ${ }^{2}$ & 124.93 & & & & \\
\hline$P$ value- chi $^{2}$ & $0.0001^{\star \star \star}$ & & & & \\
\hline $\begin{array}{l}\text { Number of } \\
\text { observations }\end{array}$ & 200 & & & & \\
\hline
\end{tabular}

\subsubsection{Factors influencing Soil Conservation}


Soil conservation is an increasingly practiced strategy among farmers around the globe (Akinnagbe and Irohibe, 2014). Results in Table 3 show that factors influencing soil conservation by the farmers in the study area. Numerous variables that have been reported to influence the adaptation in farming have been carried with respect to climate change. Education is on the top priority that has benefited environmental issues and climate change (O'Neill et al., 2020). Education plays an important role in the overall efforts towards climate change adaptation measures (Lutz et al., 2014). Lack of proper education leads to inadequate applicability of available resources. Among the significant variables, 'literary' was positive and significant with a coefficient of 0.462 and $p$-value $<0.10$. Our findings are consistent with that of Ullah and Shah, (2019). They revealed that educated farmers were more likely to practice adaptation strategies to climate-induced floods in Pakistan. Off-farm income was positively associated with soil conservation practices in the study area (Table 3). Off-farm income is an additional source that enables the farmers to adopt climate change (FAO, 2014). Similarly, land ownership was positively $(0.146)$ associated with soil conservation practices in the study area. The findings for land ownership are in agreement with Freudenberger and Miller, (2010). They revealed that land ownership and property rights are important determinants of climate change adaptation. Likewise, the variable 'erratic rain' was also found to be positive and significant with coefficient value of 0.463 and $p$-value $<0.10$. Perceived rains as source of risk is important determinant of drought adaptation strategy. The farmers who considered rains a major source of risk in the study area, they more likely to adopt the soil conservation. Likewise, the farmers were using drought resistant seeds and were practicing soil conservation for the better crop production. Moreover, the farmers have gained from their counterparts that climate adaptation increases their crop production. Therefore, they were going for soil conservation as adaptation strategy to droughts.

\subsubsection{Factors influencing Change in Crops Planting Dates}

Table 3 highlights the factors influencing the crops planting dates that were practiced by the farming community in the study area. The model results revealed that out of 14 variables seven variables were significant in association with crop planting dates. Age has a positive association with a coefficient of 0.032 , $p$-value $<0.10$ with crop planting dates. The age of farmers has significantly influenced the farmers in adoption of crop planting dates. Studies revealed that as age increases the livelihood of adaptation to climate-induced disasters increases. For instance, Ullah et al., (2015a) and Ullah and Shivakoti, (2014) revealed that as the age of farmers increased, farmers were more going for adaptation techniques in the agricultural sector. However, Ali and Erenstein, (2017), revealed a negative association between adjustment in sowing time and farmers' age in Pakistan. Similarly, farmers' experience has a positive association $(0.036, p$-value $<0.05)$ with the adaptation of change planting dates. It implies that as the farmers' experience increases, farmers were involved in changes in planting dates. Rey et al., (2017) revealed that farmers learn from experiences and bring changes to reduce drought risk. Dependent family members have a negative association with changes in planning dates. It implies that as the dependent family members increased the farmers were less likely to practice change in planting dates. Ali and Erenstein, (2017), reported that household size positively influenced the change in sowing time. However, our findings emphasis on the dependency not the household size. Perceived rain was also positive coefficient $=0.574$ and $p$-value $<0.05$. The more dependent family members compels the farmers to adopt to climate change

Loading [MathJax]/jax/output/CommonHTML/fonts/TeX/fontdata.js that large family size and high dependence led

Page $11 / 18$ 
farmers' adaptation to climate change in Pakistan. Off-farm income has positively (co-efficient $=0.511, p<$ 0.05 ) influenced adaptation of change plating dates. It implies that the farmers with more off-farm income are more likely to adopt change plating dates. A study from Nigeria by Ojo and Baiyegunhi, (2020) reported that more off-farm income increased the likelihood of adaptation to climate change. In our study, off-farm income is one of the main factors for changing cropping dates. Our study confirms the findings of Jamagani and Bivan, (2013) where they have highlighted that low income is associated with the poor diversification of agriculture and planting of farmers in the context of Nigeria. Land ownership was positively $(0.376, \mathrm{p}$-value $<0.05)$ associated with change planting dates. It implies that when the farmers are owners, they are more likely to change planting dates. Our results are in disagreement with Ali and Erenstein, (2017). They reported that land ownership was negatively associated with change in sowing time. Erratic rains risk perception was positively $(0.574$, $p$-value $<0.05)$ influencing farmers to adopt change planting dates as drought risk mitigating activity. Antwi-Agyei et al., (2018) reported that in Ghana the farmers perceived erratic rains as source of risk to their farming and practicing various adaptation strategies. Farmers' knowledge about climate change is one of the important determinants of its adaptation (Ado et al., 2019). Results show that knowledge about CC is positively $(0.845), p$-value $<0.01$ ) associated with the change in crop planting dates.

\subsubsection{Factors Influencing Ponds}

The results of the model show that age has a negative association with the pond as an adaptation strategy to droughts. It is argued that as the farmers' age increases, their knowledge about agricultural practices also increases (Ullah, 2014). Ponds needs wear and tear on regular basis. If the family has more dependent family members, they are less likely to make ponds in the fields. The variable 'land ownership' was found positive and significant with a coefficient value of 0.328 and $p$-value $<0.05$. It implies that owners of the land were more likely to make ponds in the fields. Similarly, large landholdings show the economic status of the farmers. If the farmer has more landholding size, they are adopting ponds as drought mitigating activity. Velandia et al., (2009) revealed that farmers with large landholding sizes are adopting more risk mitigating activities.

\subsubsection{Factors Influencing Terraces with Spillways}

Soil water management practices can increase resilience in the context of climate change (Kosmowski, 2018). Table 3 shows the factors influencing farmers' use of terraces with spillways. Results highlight that the variable 'age' was a positive and significant association with terraces with spillways with coefficient = 0.028 and $p$-value $<0.05$. It implies that as the age the farmer increases the likelihood of this adaptation strategy also increases. Aged farmers have experienced these methods for several years. Moreover, terraces with spillways are more technical, which is why aged farmers are going for this strategy. Likewise, the variable 'experience' was positively influencing the adaptation of terraces with spillways. Droughts are a long-run phenomenon, and this strategy the farmers are practicing in long-run disasters situations like droughts. Therefore, more experienced farmers are practicing terraces with spillways. Likewise, the variables off-farm income was found positive and significant. It implies that the farmers who had more income are practicing this strategy. This strategy needs more income and labor to contract the structures

Loading [MathJax]/jax/output/CommonHTML/fonts/TeX/fontdata.js I., (2015a) revealed that the income of farmers

Page $12 / 18$ 
influenced adaptation to climate-induced floods in Pakistan. The landholding size of farmers positively influenced their adoption of terraces with spillways. It implies that farmers with large landholdings are more likely to adopt this strategy. Knowledge about climate change was found positive and significant with a coefficient value of 0.554 and $p$-value $<0.05$. Those farmers who had knowledge about climate change were practicing terraces with spillways. According to Olazabal et al., (2018), successful adaptation to climate change needs knowledge, and understanding the complex structure and functioning.

Climate change is a real threat to farmers around the globe. Agriculture is highly dependent on including high and low temperatures, rainfall, good weather, wind intensity, and many other variables. Estimates show that climate change might reduce global agriculture productivity up to $17 \%$ by 2050 (Calmon and Feltran-Barbieri, 2019). Climate change adaptation is the action to global warming, which helps to reduce the vulnerabilities in the social and biological system (Ahmed et al., 2019). Adaptation strategies provide an opportunity to address the CC challenges and to sustain crop production (Ahmed et al., 2019).

\section{Conclusion}

Climate-induced disasters are very common around the world and affecting human societies in several ways particularly through variation in the productivity of the agriculture sector. In response to these climate risks and the drought-affected areas, the farmers are practicing several risk management activities. Farmers make choices of using strategy, which is easily and readily available at the time of climatic risk situations. Sometimes, they are making combinations of these strategies. The study areas are prone to severe droughts and are mostly rain-fed, having no irrigation system. It has been explored that the age of the farmers, their literacy, experience, dependent family members, landholding size, and land ownership, perceptions of erratic nature of rains, and climate change knowledge are important determinants of climate change adaptation strategies. Five dominant strategies were identified among the eight available strategies in the study area. These strategies were ranked and found in order as rainwater harvesting, soil conservation, change in the planting dates, building ponds, and terrace with spillways. The findings are helpful for the government in policymaking and designing programs to support farmers when they are in a drought situation. The government may extend its support to these farmers in making pond and water storage facilities.

\section{Declarations}

\section{Conflict of interest}

Authors declare that they have no conflict of interest.

\section{References}

1. Abid, M., et al., Scheffran, J., Schneider, U., \& Ashfaq, M. (2015). Farmers' perceptions of and adaptation strategies to climate change and their determinants: the case of Punjab province, Pakistan. 
2. Adaptation Fund. (2019). Enhance community, local and national-level urban climate change resilience to water scarcity, caused by floods and droughts in Rawalpindi and Nowshera: Pakistan. Washington, D.C. Available at: https://www.adaptation-fund.org/project/enhance-community-local-national-levelurban-climate-change-resilience-water-scarcity-caused-floods-droughts-rawaldpindi-now-sherapakistan/. [Accessed 24 January 2020].

3. ADB. (2009). Building Climate Resilience in the Agriculture Sector of Asia and the Pacific: Asian Development Bank Manila, Philippines.

4. Adger, W. N., Dessai, S., Goulden, M., Hulme, M., Lorenzoni, I., Nelson, D. R., . . Wreford, A. (2009). Are there social limits to adaptation to climate change? Climatic change 93(3-4), 335-354.

5. Ado, A. M., Savadogo, P., Pervez, A. K., \& Mudimu, G. T. (2019). Farmers' perceptions and adaptation strategies to climate risks and their determinants: insights from a farming community of Aguie district in Niger. GeoJournal 85(2020), 1075-1095.

6. Ahmed, I., Ullah, A., ur Rahman, M. H., Ahmad, B., Wajid, S. A., Ahmad, A., \& Ahmed, S. (2019). Climate change impacts and adaptation strategies for agronomic cropsClimate Change and Agriculture: IntechOpen.

7. Ajani, E., Mgbenka, R., \& Okeke, M. (2013). Use of indigenous knowledge as a strategy for climate change adaptation among farmers in sub-Saharan Africa: Implications for policy.

8. Akinnagbe, O. M., \& Irohibe, I. J. (2014). Agricultural adaptation strategies to climate change impacts in Africa: A review. Bangladesh Journal of Agricultural Research 39(3), 407-418.

9. Ali, A., \& Erenstein, O. (2017). Assessing farmer use of climate change adaptation practices and impacts on food security and poverty in Pakistan. Climate Risk Management 16, 183-194.

10. Antwi-Agyei, P., Dougill, A. J., Stringer, L. C., \& Codjoe, S. N. A. (2018). Adaptation opportunities and maladaptive outcomes in climate vulnerability hotspots of northern Ghana. Climate Risk Management 19(2018), 83-93.

11. Arbuckle, J. G., Morton, L. W., \& Hobbs, J. (2013). Farmer beliefs and concerns about climate change and attitudes toward adaptation and mitigation: Evidence from lowa. Climatic Change 118(3-4), 551563.

12. Ashfaq, M., Hassan, S., Naseer, M. Z., Baig, I. A., \& Asma, J. (2008). Factors Affecting Farm Diversification in Rice-Wheat. Pakistan Journal of Agricultural Sciences 45(3), 91-94.

13. Ashraf, M., Routray, J. K., \& Saeed, M. (2014). Determinants of farmers' choice of coping and adaptation measures to the drought hazard in northwest Balochistan, Pakistan. Natural hazards 73(3), 1451-1473.

14. Calmon, M., \& Feltran-Barbieri, R. (2019). 4 Ways Farmers Can Adapt to Climate Change and Generate Income. World Resource Institute. Available at: https://www.wri.org/blog/2019/12/4-ways-farmerscan-adapt-climate-change-and-generate-income. [Accessed 13 January 2020].

15. Chavas, J.-P., Chambers, R. G., \& Pope, R. D. (2010). Production economics and farm management: a century of contributions. American Journal of Agricultural Economics 92(2), 356-375. 
16. Chowdhury, M. A., Hasan, M. K., Hasan, M. R., \& Younos, T. B. (2020). Climate change impacts and adaptations on health of Internally Displaced People (IDP): An exploratory study on coastal areas of Bangladesh. Heliyon 6(9), e05018.

17. Coble, K. H., Heifner, R. G., \& Zuniga, M. (2000). Implications of crop yield and revenue insurance for producer hedging. Journal of Agricultural and Resource Economics, 432-452.

18. Cook, B. I., Smerdon, J. E., Seager, R., \& Coats, S. (2014). Global warming and 21 st century drying. Climate Dynamics 43(9-10), 2607-2627.

19. Dadzie, S. K. N., \& Acquah, H. D. (2012). Attitudes Toward Risk and Coping Responses: The Case of Food Crop Farmers at Agona Duakwa in Agona East District of Ghana. International Journal of Agriculture and Forestry 2(2), 29-37.

20. Debalke, N. M. (2013). Determinants of farmers' preference for adaptation strategies to climate change: evidence from north shoa zone of Amhara region Ethiopia. MPRA Paper(2013), 48753.

21. Deressa, T. T., Ringler, C., \& Hassan, R. M. (2010). Factors Affecting the Choices of Coping Strategies for Climate Extremes. The Case of Farmers in the Nile Basin of Ethiopia. (IFPRI Discussion Paper). Available at:

http://cdm15738.contentdm.oclc.org/utils/getfile/collection/p15738coll2/id/5198/filename/5199.pdf. [Accessed 7 November 2015].

22. EEA. (2010). Mapping the impacts of natural hazards and technological accidents in Europe. An overview of the last decade. Available at: Accessed

23. FAO. (2014). Food and Agriculture Organization. Available at: http://www.fao.org/3/i4020e/i4020e.pdf. [Accessed 5 March 2021].

24. Farooqi, A. B., Khan, A. H., \& Mir, H. (2005). Climate change perspective in Pakistan. Pakistan J. Meteorol 2(3).

25. Feder, G. (1980). Farm size, risk aversion and the adoption of new technology under uncertainty. Oxford Economic Papers 32(2), 263-283.

26. Food, F. (2003). Agricultural Organisation of the Unites Nations.(2003). Paper presented at the Responding to Agricultural and Food Insecurity Challenges Mobilising Africa to Implement Nepad Programes. Conference of ministers of agriculture of the african union, Maputo, Mozambique.

27. Frank, E., Eakin, H., \& López-Carr, D. (2011). Social identity, perception and motivation in adaptation to climate risk in the coffee sector of Chiapas, Mexico. Global environmental change21(1), 66-76.

28. Freudenberger, M., \& Miller, D. (2010). Climate Change, Property Rights, \& Resource Governance. USAID. Available at: https://www.land-links.org/issue-brief/climate-change-property-rights-and-resourcegovernance-emerging-implications-for-usg-policies-and-programming/. [Accessed 16 March 2021].

29. Gerkensmeier, B., \& Ratter, B. M. (2018). Governing coastal risks as a social process-Facilitating integrative risk management by enhanced multi-stakeholder collaboration. Environmental Science \& Policy 80, 144-151.

30. Government of Khyber Pakhtunkwa. (2014). Crop Statistics Khyber Pakhtunkhwa. Agriculture Denartment Availahle at· httn //kn anv nk/unloads/2019/05/Crops_Statistics_2013-14_KP.pdf. Loading [MathJax]/jax/output/CommonHTML/fonts/TeX/fontdata.js 
[Accessed 10 January 2020].

31. Hassan, R. M., \& Nhemachena, C. (2008). Determinants of African farmers' strategies for adapting to climate change: Multinomial choice analysis. African Journal of Agricultural and Resource Economics 2(311-2016-5521), 83-104.

32. IFRC. (2020). Annual Report 2019. Geneva. Available at: https://media.ifrc.org/ifrc/annual-report2019/.

33. IPCC. (2018). Global warming of $1.5^{\circ}$ C. Geneva, Switzerland: World Meteorological Organization.

34. Iqbal, M. A., Ping, Q., Abid, M., Kazmi, S. M. M., \& Rizwan, M. (2016). Assessing risk perceptions and attitude among cotton farmers: A case of Punjab province, Pakistan. International Journal of Disaster Risk Reduction 16, 68-74.

35. Jamagani, Z., \& Bivan, G. (2013). Factors Influencing Farmers Diversification of Their Cropping Enterprises: A Case Study of Sabon Gari Local Government Area of Kaduna State, Nigeria. Adult Education 1(2.2), 68.69.

36. Jianjun, J., Yiwei, G., Xiaomin, W., \& Nam, P. K. (2015). Farmers' risk preferences and their climate change adaptation strategies in the Yongqiao District, China. Land Use Policy 47, 365-372.

37. Just, R. E., \& Zilberman, D. (1983). Stochastic structure, farm size and technology adoption in developing agriculture. Oxford Economic Papers 35(2), 307-328.

38. Ke, B., \& Wang, H. H. (2002). An assessment of risk management strategies for grain growers in the Pacific Northwest. Agricultural Finance Review 62(2), 117-133.

39. Klopper, E., Vogel, C. H., \& Landman, W. A. (2006). Seasonal climate forecasts-potential agriculturalrisk management tools? Climatic Change 76(1-2), 73-90.

40. Kosmowski, F. (2018). Soil water management practices (terraces) helped to mitigate the $2015 \mathrm{drought}$ in Ethiopia. Agricultural water management 204, 11-16.

41. Kukkonen, M., \& Pott, L. (2019). Why the fight against climate change depends on secure land tenure. Washington DC: World Bank. Available at: https://blogs.worldbank.org/sustainablecities/why-fightagainst-climate-change-depends-secure-land-tenure. [Accessed 16 March 2020].

42. Lutz, W., Muttarak, R., \& Striessnig, E. (2014). Universal education is key to enhanced climate adaptation. Science 346(6213), 1061-1062.

43. Mesfin, W., Fufa, B., \& Haji, J. (2011). Pattern, Trend and Determinants of Crop Diversification: Empirical Evidence from Smallholders in Eastern Ethiopia. Journal of Economics and Sustainable Development 2(8), 78-89.

44. Mishra, A. K., \& Singh, V. P. (2010). A review of drought concepts. Journal of hydrology 391(1-2), 202216.

45. NCDC. (2015). Billion-dollar weather and climate disasters: Overview. Available at: http://www.ncdc.noaa.gov/billions/overview. [Accessed 15 October 2020].

46. O’Neill, B. C., Jiang, L., Samir, K., Fuchs, R., Pachauri, S., Laidlaw, E. K., . . Ren, X. (2020). The effect of education on determinants of climate change risks. Nature Sustainability 3(7), 520-528. 
47. Ojo, T., \& Baiyegunhi, L. (2020). Determinants of climate change adaptation strategies and its impact on the net farm income of rice farmers in south-west Nigeria. Land Use Policy 95, 103946.

48. Olazabal, M., Chiabai, A., Foudi, S., \& Neumann, M. B. (2018). Emergence of new knowledge for climate change adaptation. Environmental science \& policy 83, 46-53.

49. Ozor, N., Madukwe, M., Enete, A., \& Amaechina, E. (2012). A framework for agricultural adaptation to climate change in Southern Nigeria. International Journal of Agriculture Sciences 4(5), 243-252.

50. Pradeep, K., \& Mendelsohn, R. (2007). Crop selection: adapting to climate change in Africa. Policy Research Working Paper 4307.

51. Rehima, M., Belay, K., Dawit, A., \& Rashid, S. (2013). Factors affecting farmers' crops diversification: Evidence from SNNPR, Ethiopia. International Journal of Agricultural Sciences 3(6), 558-565.

52. Rey, D., Holman, I. P., \& Knox, J. W. (2017). Developing drought resilience in irrigated agriculture in the face of increasing water scarcity. Regional environmental change 17(5), 1527-1540.

53. Roka, K. (2019). Climate Change Adaptation (CCA). In W. Leal Filho, U. Azeiteiro, A. M. Azul, L. Brandli, P. G. Özuyar \& T. Wall (Eds.), Climate Action (pp. 1-13). Cham: Springer International Publishing.

54. Salmoral, G., Ababio, B., \& Holman, I. P. (2020). Drought Impacts, Coping Responses and Adaptation in the UK Outdoor Livestock Sector: Insights to Increase Drought Resilience. Land 9(6), 202.

55. Saqib, S. E., Ahmad, M. M., Panezai, S., \& Ali, U. (2016a). Factors influencing farmers' adoption of agricultural credit as a risk management strategy: The case of Pakistan. International Journal of Disaster Risk Reduction 17, 67-76.

56. Saqib, S. E., Ahmad, M. M., Panezai, S., \& Rana, I. A. (2016b). An empirical assessment of farmers' risk attitudes in flood-prone areas of Pakistan. International journal of disaster risk reduction 18, 107-114. doi: 10.1016/j.ijdrr.2016.06.007

57. Sivakumar, M. V., Stefanski, R., Bazza, M., Zelaya, S., Wilhite, D., \& Magalhaes, A. R. (2014). High level meeting on national drought policy: summary and major outcomes. Weather and climate Extremes 3 , 126-132.

58. Tam, J., \& McDaniels, T. L. (2013). Understanding individual risk perceptions and preferences for climate change adaptations in biological conservation. Environmental Science \& Policy 27, 114-123.

59. Ullah, R. (2014). Production Risk Management and Its Impacts at the Farm Level: The Case of Paksitan. Doctor,(Ph. D. Thesis), Asian Institute of Technology.

60. Ullah, R., Jourdain, D., Shivakoti, G. P., \& Dhakal, S. (2015a). Managing catastrophic risks in agriculture: Simultaneous adoption of diversification and precautionary savings. International Journal of Disaster Risk Reduction 12, 268-277. doi: 10.1016/j.ijdrr.2015.02.001

61. Ullah, R., \& Shah, J. (2019). Economic costs of managing climatic risks in agriculture: Evidences from Khyber Pakhtunkhwa Province of Pakistan. Sarhad Journal of Agriculture 35(1), 155-160.

62. Ullah, R., \& Shivakoti, G. P. (2014). Adoption of on-farm and off-farm diversification to manage agricultural risks: Are these decisions correlated? Outlook on AGRICULTURE 43(4), 265-271.

63. Ullah, R., Shivakoti, G. P., \& Ali, G. (2015b). Factors effecting farmers' risk attitude and risk perceptions: 
157. doi: $10.1016 / j . i j d r r .2015 .05 .005$

64. Ullah, W., Nafees, M., Khurshid, M., \& Nihei, T. (2019). Assessing farmers' perspectives on climate change for effective farm-level adaptation measures in Khyber Pakhtunkhwa, Pakistan. Environmental monitoring and assessment 191(9), 547.

65. Velandia, M., Rejesus, R. M., Knight, T. O., \& Sherrick, B. J. (2009). Factors affecting farmers' utilization of agricultural risk management tools: the case of crop insurance, forward contracting, and spreading sales. Journal of agricultural and applied economics 41(1), 107-123.

66. World Bank. (2019). Improved Irrigation, Better Crops for Khyber Pakhtunkhwa Farmers. Washington. Available at: https://reliefweb.int/report/pakistan/improved-irrigation-better-crops-khyberpakhtunkhwa-farmers. [Accessed 23 March 2020].

67. Yamane, T. (1967). Statistics: an introductory analysis, 2nd edn, Harper and Row, New York.

68. Zulfiqar, F., Ullah, R., Abid, M., \& Hussain, A. (2016). Cotton production under risk: a simultaneous adoption of risk coping tools. Natural Hazards 84(2), 959-974. 